\title{
Critical Philosophy of Mind: The Transcendental Idealistic Perspective
}

\author{
ALEXANDER MUSS \\ Laboratory of Psychophysiology, Faculty of Psychology, St. Petersburg State University, 6 Makarova Embankment, 199034, St. Petersburg \\ Email albertwanderer@gmail.com
}

\begin{abstract}
Modern philosophy of mind, in collaboration with cognitive science, tries to clarify both hard and easy problems of consciousness. The analytical philosophy here provides two opportunities. On the one hand, for cognitive scientists and philosophers of mind, these problems seem to be solved, while, on the other hand, these solutions do not satisfy some other researchers. In this article, the author tries to discuss problems caused by these solutions and argues why the problems of consciousness cannot be solved without a systematic philosophical approach using some findings from the continental philosophy, especially Kantian transcendental philosophy, phenomenology and philosophical anthropology. In combination with findings from science and analytical philosophy, the examined ideas would help researchers to develop more consistent knowledge of mind and consciousness.
\end{abstract}

Keywords: mind, consciousness, critical philosophy, transcendental idealism, metaphysics

\section{INTRODUCTION}

Contemporary philosophy of mind raises different questions necessary for both philosophy and science. Within formulation of the hard (Chalmers 1996) and the harder problem (Block 2002: 391-425) of consciousness, discussions of the last five years highlighted the question of the subjective point of view of the embodied and embedded creature (Neisser 2017; Schlicht 2018) as well as of the nature and features of mental causation (Bernstein, Wilson 2016), and also inability to solve those problems (Chalmers 2017). The first aspect shows not only a connection between the problems of the philosophy of mind with modern cognitive research, but also the way of using classic philosophical conceptions, such as Kantian critical philosophy. The second way shows the connection between the modern disputes about mental causation with the fundamental problem of free will.

This article, focused mostly on the first aspect, provides both the problems of consciousness and solutions via analytical philosophy to justify the fact that these problems could be solved only in philosophy itself. Moreover, I would like to show that opportunities to overcome such problems could be provided by continental philosophy, as the philosophical tradition that can study a complex subject in its context: transcendental philosophy, phenomenology and philosophical anthropology. The main method of this study is Foucault's analysis 
of the discourse of knowledge (Foucault 1970): during the research, I compare different ideas from both analytical and continental philosophy in its application to mind and consciousness.

\section{TWO WAYS OF STUDYING MIND AND CONSCIOUSNESS IN ANALYTICAL PHILOSOPHY}

The problem of consciousness has a long lasting history from Cartesian dualism to the modern philosophy of mind, Dennett's and Churchland's optimism, Searles' skepticism and Chalmers' pessimism (Revonsuo 2009: 177-228). Results of the contemporary research divide philosophy of mind into two different approaches. The first approach leaves problems of consciousness already solved through the data from modern neurocognitive science. The second one provides the general idea of restrictions of such solutions and demands more quite different solutions that should change our worldview.

Let us try to provide concrete examples of the both approaches. According to Fodor's functionalism, we do not need to explain consciousness itself, but we need to understand its functions (Fodor 1983). Then biological-information explanation by Dennett provides the functions of consciousness, criticizes the hard problem using contemporary neurocognitive data and the language criticism from analytical philosophy (Dennett 1991, 1996).

Churchland's criticism changes the focus and states the hard problem above the aim of scientific research: our subjective knowledge of consciousness is quite different from scientific theories, so we do not need to rely on this 'folk-psychology' while studying consciousness as scientific phenomenon (Churchland 2005: 155-174). As a result, for these researchers subjective experience (consciousness) is possibly a computable information process, which is critical for human adaptation.

As I mentioned above, this model of human has its application field and its restrictions. For example, Searle argues that mind and consciousness are not something that could be computed and executed as a computer program. His criticism is based on the idea that only syntax could be computable, but we are unable to compute semantics. Both of them are the products of our consciousness, so we are unable to compute it (Searle 1992).

Moreover, Chalmers starts to solve the hard problem with the idea of psychophysiological laws and finishes with the idea that all his previous attempts could not solve it. His panpsychism is something new in such way of philosophizing, but it contradicts both contemporary physicalism and scientific infiltration into the philosophical way of thinking (Chalmers 1996). But later articles of Chalmers show that his attempts do not provide any suitable solution (Chalmers 2017).

In addition, Vacariu argues that the hard problem is unsolvable because of its formulation in 'epistemically different worlds' (the formulation of the essence of subjective experience and its biological-information correlates are incoherent), which prevents any possible solutions (Vacariu 2005: 515-548). Thus, the problems of consciousness may lie not in our empirical data, but in our ways of theorizing.

\section{SOME KEY IDEAS FROM CONTINENTAL PHILOSOPHY}

In order to update these ways, we need to connect not our naive language from the first-person perspective to the scientific third-one, but theory, which provides the perspective gone along these differences, as Gehlen's anthropology uses the concept of action instead of the mindbody dualism (Gehlen 1942: 1-53). In other words, Copernic does not ruin our experience of the Sun moving around the Earth, but explains why we have such a perception and connects 
them to astronomical calculations. Then the problem of consciousness is also a problem of the both ontological and epistemic status of the subjective experience.

So, when the problem of consciousness seems to be unsolvable by analytical philosophy, we should find the other way, which is based on consistent theory. Then this consistency needs not only carefully received data, but also well-formulated theory, aimed at both interpretation and predictions. In other words, consciousness as the study object needs both empirical and theoretical systematization, and the theoretical one contains metaphysics. And I would like to use Kantian ideas to develop the new way of theorizing about consciousness.

In order to provide a systematic theoretical observation of consciousness, we should start with Cartesian dualism as the core theoretical construction and the core problem of contemporary philosophy of mind. In the history of philosophy there are a lot of sources of metaphysical theorization that try to overwhelm this dualism and its consequences from the controversial Cartesian idea of interaction between the mind and the material body, Leibniz's psychophysiological parallelism, Lamettrie's mechanization, and also Barclay and Hume's ideas, which lead to both empirical science and solipsism (Revonsuo 2009: 3-68).

Moreover, there are some later authors who provide new original ways of fighting the Cartesian dualism, such as Husserl's phenomenology and philosophical anthropology by Plessner, Scheler and Gehlen, which already denies or advocates such dualistic nature of our knowledge of consciousness. Those critics are still interesting for philosophers of mind, help them to develop new ways of consciousness study, but there is one author who could possibly help the philosopher and researcher to go beyond the disconnection of old theoretical traps and contemporary empirical data without their devaluation. This author is I. Kant with his 'Critique of Pure Reason'.

In this case the method of our research is the Kantian critical method with his transcendental-idealistic prospective, which we would combine with some essential findings from phenomenology (Husserl's epoch, his idea of pure consciousness and his critical issues about mathematization of knowledge; Sartre's ideas of artificial nature of human ego), philosophical anthropology (Gehlen's idea of action as combination of mental and material in human, Plessner's apology of the dualistic nature of human), Foucault's critical ideas (the relativity of a priori knowledge) and the contemporary philosophy of mind (the hard and the harder problems).

Thus, in this article we combine the following ideas: from the impossibility of the hard (Chalmers 2017) and the harder problems of consciousness (Block 2002: 391-425), critics to studying mind as something computable (Searle 1992) and Husserlian criticism of mathematization of knowledge in general (Husserl 1970) to the necessity of epoch, when we try to study mind and consciousness (Husserl 1982: 21), to the general idea of transcendental idealism, which differ a priori and a posteriori knowledge, empirical and transcendental one, the principal difference between inner and outer experience (Kant 1998: 327-337). This provides an opportunity to evaluate both inner (which possibly includes modern concepts of categorization and thinking, and, more generally, consciousness itself) and outer (which possibly includes modern concept of perception, and, more generally, our empirical data) experience as different sources of knowledge and something irreducible but reinterpretable to each other. According to the Kantian view on things in itself (Kant 1998: 161) and Sartre's views (Sartre 1991: 88-89) on the artificial nature of human ego, we should search for and study something different from it. In this case, the Husserlian idea (Husserl 1982: 37) of pure consciousness could be useful, but it lies totally beyond our experience - this is a theoretical concept. 
It is also important that we do not have enough evidence to use Kantian forms of a priori knowledge, because M. Foucault in his book 'The Order of Things' shows the relativity of such a priories, which depends on both actual discourse and the concrete philosopher, who defines such a priories (Foucault 1970: 265-266). Moreover, nowadays space and time in their empirical form are useful in both science and analytical philosophy, and these concepts are also useful in mathematical modelling of the natural processes as a coordinate system and possible parameters. So in philosophy of mind, which is able to solve the problem of consciousness, we need, according to Chalmers (Chalmers 1996), the other basis. Thus, from this modification of the transcendental idealistic point of view provides the following view on both mind and consciousness.

One of possible objections is that cognitive science itself has consistent theories of mind and consciousness, which have their own opportunities and limitations, e.g. Baars Cartesian theater metaphor (1997), Tonony's information integration theory (Tonony 2008: 216-242), Allakhverdow's theory of cognitive consciousness and unconsciousness (Allakhverdow 2009: 124-140), etc. All these theories are based on only empirical data, and, therefore, they can do nothing with the antinomies of pure mind mentioned by Kant (Kant: 459-523). Some other opportunities, like Gehlen's anthropology, which are able to solve the mind-body problem in research are also unable to solve these antinomies.

Thus, all these ideas from continental philosophy could provide a new perspective for studying mind and consciousness, but this perspective prevents us from apology of the contemporary science and returns us to the philosophy and metaphysics itself with their own foundations. From my point of view, this idea corresponds with Badiou's idea (1999: 37, 6168 ) of the philosophy whereby the science is only one of the four necessary truth procedures.

So, Kantian transcendental idealism with some additional ideas from the latter authors allows new description of problems of consciousness. This description would be useful if the first way to develop the problems is wrong or has some significant limitations.

From one point, a number of these limitations such as the problem of computation, and the hard and the harder problems of consciousness are already given by Searle, Chalmers, Nagel (Nagel 1974: 435-450) and Block. They provide a number of observable phenomena and logical arguments, which cannot be answered via contemporary philosophy of mind. But their ideas, which should exceed the current conceptions, are already pointless: there are lots of criticisms, but only a few basic conceptualizations (such as Chalmers' (1996) early project of dualistic psychophysical natural laws), which remain without impact and later development.

From the other one, Husserl, Rickert, Badiou and Vacariu point to the more general restrictions - restriction of the way of philosophizing: replacement of natural laws by mathematical ones (Husserl 1970), inconsistency of mental and material while providing dualistic conceptions (Rickert 1900: 59-88), the suture between science and philosophy, which ignores the other truth procedures (Badiou 1999: 61-68), and the existence of different philosophical languages that are totally inconsistent (Vacariu 2005: 515-548).

Thus, when philosophy tries to apologize to science, it provides no additional data about the object of interest - consciousness, because contemporary science already provides it via its own methodology and results. Then it is necessary to undo the 'seam' between philosophical and scientific studies of consciousness.

Therefore, in order to obtain its own knowledge about consciousness, philosophy should develop its own foundations. Continental philosophy, especially Kantian transcendental idealism, could give us such basis, which allows us to stay with both our inner and outer experience. 


\section{TRANSCENDENTAL IDEALISTIC VIEW ON THE PROBLEMS OF CONSCIOUSNESS}

Let us try to reformulate the problems of consciousness with such a basis. Then the hard problem of consciousness from the problem of qualia transforms into the question whether we should ignore our inner experience or keep it away from philosophical investigation.

According to Kant (Kant: 524-550), inner (consciousness) and outer experience is not a problem itself, but the source of our knowledge. In this case, we should not ignore subjective experience, approving not only its ontological, but also epistemic status. Therefore, the main question here is the question about sources of our consciousness (our inner/subjective experience) - the mind (as something that has and possibly uses experience) lies beyond our experience, but we are able to formulate some consistent conceptions, which help us to broaden our knowledge.

In this case our mind is something different from our Self, because the Self is only a post hoc construct of our mind (Sartre 1991: 88-89), or an illusion (Metzinger 2003: 625-626). Nevertheless, the mind is not the Self because it is already a construct in our experience. Besides, the mind (something that operates experience) and consciousness (inner and outer experience) are irreducible to computations, because mathematics deals only with our empirical data, which are also the product of our mind, according to the previous statement, because the question of mind lies beyond our experience. This is consistent with recent discussions in analytical philosophy, in which researchers study the subject of experience via the subjective point of view both embodied and embedded (Neisser 2017; Schlicht 2018).

This statement causes the following question: how can we provide any sustainable solutions that could possibly crack open the essence of mind? I am sure that we should continue from the following point: while philosophizing, we should use more than one truth procedure, and also we should rely on available properties of mind, such as our cognition in general, imitation, creative activities, etc., and also our subjective experience of being such a creature. Then we are able to ask such questions about mind available for our experience. When we are trying to model human cognition and behaviour, scientists provide models (Simon 1996) that can function without any subjective experience such as Chalmers' philosophical zombie (Chalmers 1996: 94).

At the same time, while playing roles, scripts and fictions, authors and actors (also it could be possible via communications, empathy, reading, playing role and computer games or during some altered states of consciousness and mental disorders) are able to model or imitate other human thinking, feeling and behaviour using their own and also fictional subjective experience. However, while doing so and while imaging some transcendental beings, mind uses its own traits. It is like such defense mechanism as projection (Freud 1993: 200-201).

In other words, mind is able to solve the task via modelling the foreign subjective experience or via computing. In both cases, mind is unable to totally refuse its own experience, so we can define mind as something able to do such task with the observable limitations. The main restriction of this conception is the necessity of the reinterpretation of our scientific knowledge to make it coherent to such conception. Moreover, this conception is not something that could be the one final answer to the question of mind and consciousness.

\section{CONCLUSIONS}

The question about mind and consciousness is a philosophical question, which could provide some scientifically useful implications. Using Kantian transcendental philosophy and some other ideas from continental philosophy as the methodological framework enables us to reattribute 
the question of consciousness to the question of mind. However, within the provided framework this question would have only a hypothetical answer, which could be possibly evaluated through its consistency and heuristics.

This position denies any final answers and also provides a necessity to reattribute any empirical data to such a conception, but it defends the ontological and epistemic status of subjective experience. There is a continuum between Chalmers' philosophical zombie and other human models, which behaves like an automaton without subjective experience, and Kantian moral god, which is something absolute but also the construct of someone's mind, or Allakhverdow's cognitive unconsciousness, which knows everything and uses consciousness as a testing mechanism. In between, there are varieties of ways to simulate subjective experiences of others via our minds.

Thus, all of these theoretical concepts are such possible states of mind, which we can compare via its limits and opportunities. So, such a conceptualization allows a systematic view on mind and consciousness, which relies on different truth procedures described by Badiou.

Received 2 January 2019

Accepted 29 January 2020

\section{References}

1. Allakhverdow, V. M. 2009. 'The Role of Consciousness in Human Cognitive Activity', Psychology in Russia 2: 124-140.

2. Badiou, A. 1999. Manifesto for Philosophy. SUNY Press.

3. Bernstein, S.; Wilson, J. 2016. 'Free Will and Mental Quausation', Journal of the American Philosophical Association 2(2): 310-331.

4. Block, N. 2002. 'The Harder Problem of Consciousness', The Journal of Philosophy XCIX(8): 391-425.

5. Chalmers, D. 1996. The Conscious Mind in Search of a Fundamental Theory. New York: Oxford University Press.

6. Chalmers, D. 2017. 'Idealism and the Mind-Body Problem', in The Routledge Handbook to Panpsychism, ed. W. Seager. Routledge.

7. Churchland, P. 2005. 'Eliminative Materialism and the Prepositional Attitudes', in Contemporary Materialism: A Reader, eds. P. K. Moser and J. D. Trout. London, New York: Routledge, 155-174.

8. Dennet, D. C. 1991. Consciousness Explained. New York, Boston, London: Back Bay Books, Little, Brown and Company.

9. Dennet, D. C. 1996. Kinds of Minds. New York: Basic Books.

10. Fodor, J. 1983. The Modularity of Mind. Cambridge, Massachusets: The MIT Press.

11. Freud, S. 1993. 'On Psychopatology', in The Penguin Freud Library, Vol. 10: On Psychopathology: Inhibitions, Symptons And Anxiety And Other Works. Penguin Books, 200-201.

12. Gehlen, A. 1942. 'Zur Systematik der Anthropologie', in Systematische Philosophie, ed. N. Hartmann. Stuttgart/Berlin: Kohlhammer, 1-53.

13. Husserl, E. 1970. The Crisis of European Sciences and Transcendental Phenomenology: An Introduction to Phenomenological Philosophy. Evanston: Northwestern University Press.

14. Husserl, E. 1982. Cartesian Meditations. An Introduction to Phenomenology. The Hague, Boston, London: Martinus Nijhoff Publishers.

15. Kant, I. 1998. Critique of Pure Reason. Cambridge: Cambridge University Press.

16. Metzinger, T. 2003. Being No One. The Self-Model Theory of Subjectivity. Cambridge, Massachusets: The MIT Press.

17. Nagel, T. 1974. 'What Is It Like To Be a Bat?', The Philosophical Review 83(4): 435-450.

18. Neisser, J. 2017. 'What Subjectivity Is Not', Topoi 36(1): 41-53.

19. Revonsuo, A. 2009. Consciousness: The Science of Subjectivity. Hove, New York: Psychology Press.

20. Rickert, H. 1900. 'Psychophysische Causalität und psychophysischer Parallelismus', in Philosophische Abhandlungen, ed. C. Sigwart. Tübingen, Freiburg, Leipzig: Verlag von J. C. B. Mohk (Paul Siebeck), 59-88.

21. Sartre, J.-P. 1991. The Transcendence of the Ego. New York: Hill and Wang. 
22. Schlicht, T. 2018. 'Experiencing Organisms: From Mineness to Subject of Experience', Philosophical Studies 175(10): 2447-2474.

23. Searle, J. 1992. The Rediscovery of the Mind. Cambridge, Massachusets; London, England: The MIT Press.

24. Simon, H. A. 1996. The Sciences of the Artificial. Cambridge, Massachusets; London, England: The MIT Press.

25. Vacariu, G. 2005. 'Mind, Brain, and Epistemologically Different Worlds', Synthese 147: 515-548, $515-548$.

\title{
ALEKSANDER MUSS
}

\section{Kritinè proto filosofija: transcendentalinė idealistinė perspektyva}

\begin{abstract}
Santrauka
Šiuolaikinè proto filosofija kartu su kognityviniais mokslais siekia išspręsti sunkias ir lengvas sąmonès aiškinimo problemas. Šias problemas analitinès filosofijos atstovai suvokia dvejopai. Vieniems atrodo, kad minètos problemos jau išspręstos, kiti mano, kad tie sprendimai yra netinkami. Straipsnio autorius aptaria problemas, su kuriomis susidūrè analitinès filosofijos atstovai aiškindami sąmonę. Jis siekia parodyti, kad sąmonès aiškinimo problemos gali būti išspręstos tik pasitelkus sisteminị filosofinį požiūrị, besiremiantị kontinentinès filosofijos, ypač Immanuelio Kanto transcendentalinès filosofijos, fenomenologijos ir filosofinès antropologijos, įžvalgomis. Straipsnio autorius ìsitikinęs, kad jo siūlomas požiūris, derinamas su analitinès filosofijos prielaidomis ir mokslo duomenimis, sudaro sąlygas ịgyti nuoseklesnị proto ir sąmonès supratimą.
\end{abstract}

Raktažodžiai: protas, sąmonè, kritinè filosofija, transcendentalinis idealizmas, metafizika 